FACTA UNIVERSITATIS

Series: Physical Education and Sport, Vol. 18, No 1, 2020, pp. 49 - 63

https://doi.org/10.22190/FUPES200114006M

Research article

\title{
MOTOR SKILLS OF SOCCER PLAYERS AGED 16-18 IN REGARD TO COMPETITION LEVEL AND PLAYING POSITION
}

\author{
UDC 797.323.012
}

\section{Zoran Momčilović ${ }^{1}$, Srđan Marković ${ }^{2}$, Dragana Bogavac ${ }^{3}$, Tatjana Milosavljević Đukić ${ }^{1}$, Srđan Bugarski ${ }^{4}$}

\author{
${ }^{1}$ Pedagogical Faculty, University of Niš, Vranje, Serbia \\ ${ }^{2}$ Faculty of Physical Education and Sports Management, University Singidunum, \\ Belgrade, Serbia \\ ${ }^{3}$ Teacher Education Faculty, University of Belgrade, Belgrade, Serbia \\ ${ }^{4}$ F.C. Crvena Zvezda, Belgrade, Serbia
}

\begin{abstract}
The aim of this paper was to examine the differences in the motor skills of soccer players aged 16-18 years who play in different competition levels (National League and Regional League), as well as players who play in different positions in the team. The standard testing battery for the motor skills assessment of soccer players was used to evaluate the motor skills. As for the evaluation of the differences between the different playing positions, a two-factor ANOVA with the factor Competition Level (National and Regional Level) and the factor Position (forward, midfielder, side defender, central defender) was used. A two-factor ANOVA with the factor Competition Level (National and Regional Level) and the factor Age (16, 17 and 18 years of age) was used to evaluate the differences between the different quality levels. The study included 126 male soccer players 16 to 18 years of age $\left(N_{16}=45, N_{17}=41, N_{18}=40\right)$ divided into 4 positions on the team: forwards (N=37, $B H=179.2 \pm 5.0, B M=70.1 \pm 6.6)$, midfielders $(N=48, B H=177.9 \pm 6.3$, $B M=69.6 \pm 7.9)$, side defenders $(N=22, B H=176.6 \pm 5.4, B M=67.5 \pm 5.7)$ and central defenders $(N=19, \quad B H=184.0 \pm 4.3, \quad B M=72.3 \pm 6.6)$. Because of significantly different activities in the field, the goalkeeper position was excluded from this study. The results indicate that motor skills do not differentiate players of different competition levels, and that there is a gap between players aged 18 years in aerobic endurance which is the basis of success in soccer. Also, the obtained results suggest that motor skills could differentiate players at certain positions. However, it was specifically found that only alactic capabilities type of speed and agility, differentiate forwards from other positions, especially from midfielders.
\end{abstract}

Key words: Soccer, Motor Skills, Team Position, Competition Level, Youth Players.

Received January 14, 2020/ Accepted April 6, 2020

Corresponding author: Zoran Momčilović

Pedagogical Faculty, University of Niš, Partizanska 14, 17500, Vranje, Serbia

Phone: + 17 421633•E-mail: z_momcilovic@yahoo.com 


\section{INTRODUCTION}

The game of soccer has been constantly evolving since its origins both in terms of the game as a whole, and of the transformation of individuals as an integral and indivisible part of soccer game. The present level of soccer development characterized by great dynamics and high rhythm of the game requires exceptional physical preparedness, high levels of movement technique (Sever \& Zorba, 2017), tactical awareness and mental stability.

During a soccer game, players perform a variety of activities and movements with the ball and without it. In doing so, players unintentionally (and unexpectedly) change the intervals of high and low intensity, as well as their duration. Therefore, the game of soccer can be described as a complex activity with acyclic intervals. During a match, a player performs between 1400 and 1600 changes of intensity and direction of movement, or changes every 3.5-4 seconds (Verheijen, 1998). On the other hand, players sprint every 90 seconds, on average, and have high-intensity efforts every 30 seconds (Reilly, Bangsbo, \& Franks, 2000). Players with a high level of motor and functional abilities can exert adequate technical-tactical skills throughout the duration of a match.

Otherwise, it is well-known that one soccer team consists of 11 players in the field (including the goalkeeper) and who are, based on their activities, position in the field and the tasks arising from these positions, classified as defenders, midfielders and forwards (Commeti, Maffiuletti, Pousson, Chatard, \& Maffulli, 2001; Vaeyens et al., 2006). Such a classification and division of players within a team results in different requirements in technical, tactical, morphological, functional, motor, psychological manifestations of each individual based on their position on the team (Di Salvo et al., 2007).

Although modern players should be able to play in different positions, the truth is that every position on the team is associated with a number of specific tasks.

With regard to the competition level, the distance covered in high intensity is an important criterion for the division of top players and those with lower skills (Jovanović, Sporiš, Omrcen, \& Fiorentini, 2011). Mohr, Krustrup, P., \& Bangsbo (2003) found that highlevel players cover $28-58 \%$ longer distances of running at high intensity $(>19 \mathrm{~km} / \mathrm{h})$ and sprint, compared to players playing at lower levels [high intensity running $2.43 \pm 0.14 \mathrm{~km}$ vs. $1.90 \pm 0.12 \mathrm{~km}$ : sprint $0.65 \pm 0.06 \mathrm{~km}$ vs. $0.41 \pm 0.03 \mathrm{~km}$ (Mean \pm SD). Accordingly, there was a significant difference in the endurance of the soccer players at various competition levels measured by different tests, both among the senior, as well as in junior players (Krustrup et al, 2006; Rostgaard, Iaia, Simonsen, \& Bangsbo, 2008; Rebelo et al., 2013).

Motor skills have a greater discriminatory power than anthropometric characteristics and therefore can be taken as a primary element of identification and selection of young players. It is widely known that players at the highest competition level have the highest level of motor skills in general. Therefore, the results successively decrease as we reach lower competition levels. Differences are mainly manifested in those variables that are more strongly influenced by the training procedure (Joksimović et al., 2008).

Previous studies have shown that professional players in European leagues performed sprints within 5 s in $90 \%$ of cases (Andrzejewski, Chmura, Pluta, Strzelczyk, \& Kasprzak, 2012). Therefore, the ability to accelerate within a maximum of 5 seconds stands out as an important factor of success in soccer. Thus, elite players had significantly higher speed levels on the $10 \mathrm{~m}$ sprint compared to lower competition level players (Pssota, Bunc, Netscher, Mahrová, \& Nováková, 2006; Haugen, Tønnessen, \& Seiler, 2012). 
When it comes to game requests, a high level of explosive power is an advantage in the individual tackles in the air and, consequently, in the running economy. That conclusion has been made due to a significant correlation between the sprint at 10 to $30 \mathrm{~m}$ and vertical jumps in elite players (Wisløff, Castanga, Helgerud, Jones, \& Hoff, 2004). Significantly higher values of lactate tolerance, isokinetic knee extensor strength and vertical jump ability were found in players whose teams achieved better results at the national level (Kalapotharakos et al., 2006). These results were also confirmed at the international level, where significant differences were observed in the explosive abilities measured by different vertical jumps between European and African players on the one hand, and Asian players, on the other (Wong \& Wong, 2009), but also between Spanish and Icelandic players (Arnason et al., 2004; Casajüs, 2001).

Some players may be more genetically adaptable to training stimuli, particularly with respect to the relative distribution of muscle fibers. Therefore, physiological responses to exercise can be highly dependent on dominant muscle fiber type (Reilly et al., 2000).

Professional soccer today is played at a higher pace than 20-30 years ago. Therefore, it is likely that the physiological factors of high rates of energy production during the match gained significance in the context of raising functional abilities of soccer players. For example, values of aerobic power, such as maximum oxygen uptake (VO2max) can have a greater influence on successful performance. Consequently, having a relatively high threshold of oxygen utilization can be an important criterion in the assessment of youngsters. However, it is doubtful how present the level indicators of high fitness are from childhood to adulthood (Reilly, Williams, Nevill, \& Franks, 2000).

Soccer is a team sport, and therefore a win against an opponent, as the ultimate goal in a soccer match, depends both on the quality of each individual player, and on compatibility between them (Gil, Ruiz, Irazusta, Gil, \& Irazusta, 2007). Therefore, for greater efficiency, the players are placed in different positions in order to meet specific tasks and provide team superiority (Stølen, Chamari, Castagna, \& Wisløff, 2005; Wong \& Wong, 2009). During the game, players at different positions have different requirements. Therefore, midfielders cover the greatest distance (between 10 and $13 \mathrm{~km}$ ), compared to the other players, while goalkeepers run around 4km in 90 minutes (Wisløff, Helgerud, \& Hoff, 1998). Given the fact that there are different requirements in the match, differences were found in elite players based on their physical characteristics in different positions they play.

Most of the research has shown that explosive activities, like speed and agility do not differentiate players by playing position (Dauty, Bryand, \& Potiron-Josse, 2002; Strudwick, Reilly, \& Doran, 2002; Rampinini et al., 2007; Wisløff et al., 2004; Taskinen, 2008). There are several studies that have shown better results of forwards compared to other positions with regard to the sprint up to 20 m (Sporiš, Jukić, Ostojić, \& Milanović, 2009; Pivovarniček, Pupiš, Tonhauserová, \& Tokárová, 2013). On the other hand, in jumping activities, measured by squat jumps and countermovement jumps with an arm swing, significantly better results were observed in goalkeepers and central defenders (Lago-Penas, Lago-Ballesteros, \& Rey, 2011; Boone, Vaeyens, Steyaert, Vanden Bossche, \& Bourgois, 2012), while midfielders showed significantly lower scores than other positions on the team (Haugen et al., 2013).

The aim of this paper was to examine differences in motor skills of soccer players aged 16-18 years who play in different competition levels (National League and Regional League), as well as players who play in different positions on the team. 


\section{METHODS}

The study included 126 soccer players, aged 16 to 18 years ( 16 years $\mathrm{N}=45,17$ years $\mathrm{N}=41,18$ years $\mathrm{N}=40)$, divided into 4 positions: forwards $(\mathrm{N}=37, \mathrm{BH}=179.2 \pm 5.0 \mathrm{~cm}$, $\mathrm{BM}=70.1 \pm 6.6 \mathrm{~kg}$, Mean $\pm \mathrm{SD})$, midfielders $(\mathrm{N}=48, \mathrm{BH}=177.9 \pm 6.3 \mathrm{~cm}, \mathrm{BM}=69.6 \pm 7.9 \mathrm{~kg}$, Mean \pm SD), side defenders $(\mathrm{N}=22, \mathrm{BH}=176.6 \pm 5.4 \mathrm{~cm}, \mathrm{BM}=67.5 \pm 5.7 \mathrm{~kg}, \mathrm{Mean} \pm \mathrm{SD})$ and central defenders $(\mathrm{N}=19, \mathrm{BH}=184.0 \pm 4.3 \mathrm{~cm}, \mathrm{BM}=72.3 \pm 6.6 \mathrm{~kg}$, Mean $\pm \mathrm{SD})$. As the goalkeeper's activities are fundamentally different from other players, the goalkeeper's position was excluded from the study. All of the participants actively exercise in their teams. They are members of competitive selections, each in their own age group.

This research was conducted on the basis of standard testing of motor skills in young soccer players, members of the club whose selections compete in the highest ranking of competitions in Serbia (U19 and U17 League of Serbia; N=52) and the club whose selections compete in the second highest ranking competitions in Serbia (Belgrade U19 and U17 League; $\mathrm{N}=74$ ). The testing was done in two days, seven days before the start of the championship, after all the tested teams had passed the entire preparatory period with the team. Each test was performed on an outdoor soccer pitch with artificial turf, jumping tests on a hard surface, while anthropometric tests and the Sit \& Reach test were done at the club premises. Every participant wore the appropriate sports equipment.

A standard battery of tests was used to assess the motor skills of soccer players, which provide a total of 12 dependent variables to assess speed, agility, leg muscle power, speed endurance, endurance and flexibility.

The acceleration, i.e., the player speed, is estimated by a test in which the task is to run at maximum speed for 30 meters. During the testing, three variables were obtained: time in Sprint at 10m - S10M (in s); time in Sprint at 20m with flying start - S20MF (in s); time in Sprint at 30m - S30M (in s). The start of the measurement is defined by the intersection of the infrared ray of the first photocell, while the end is defined by the intersection of the infrared ray of the last, third photocell.

The agility, i.e., the acceleration, deceleration, rapid change of direction of movement, is estimated on the basis of the time for running a total distance of 20 meters, in the so-called zigzag trajectory. According to the testing protocols, the participants performed this test: without a ball - ZIGZAG (in s); and with a ball - ZIGZAGBALL (in s). The beginning of the measurement is defined by the intersection of the infrared ray of the first photocell, while the end is defined by the intersection of the infrared ray of the second photocell.

The leg muscle power, i.e., the assessment of the ability to perform maximum jumps, was performed by a test where the task was to achieve the maximum vertical height of the jump, by: leaping from the semi-squat - SJ (in $\mathrm{cm}$ ), which assesses the explosive power of the lower extremities, especially knee extensors muscles; then jumps which contain elements of countermovement - CMJ (in cm); and arm swing - CMJA (in $\mathrm{cm}$ ), which were used to estimate the relative contribution of elastic potential, and the post-active transfer (arm swing). An infrared sensory mat was used for these tests to measure the jump height based on the duration of the flight phase.

The speed endurance was assessed using the 6 repetitive sprints at 30 meters, with a 10 second recovery time between sprints (modified RAST test). The assessment was made on the basis of: the average time of 6 sprints - RASTAVG (in s); as well as the ratio of fastest and slowest attempts - RAST\% (in \%). The beginning and end of the test, as in the speed and agility tests, are defined by the intersection of the infrared ray of the photocells. 
The aerobic endurance was evaluated on the basis of the total distance covered in the YoYo Intermittent Recovery Test - Level 1 - YOYO_IR_1 (in m). This test was performed by running $20 \mathrm{~m}$ back and forth, with pace dictated by an audio signal followed by a 10 second pause to walk $5 \mathrm{~m}$ back and forth. The pace of running increased progressively according to the test protocol, to the point where the participant was unable to follow the pace dictated by the audio signal.

The Sit \& Reach test - S\&R (in cm) was used to assess the flexibility of the hip extensors and lower back muscles, using a standard bench.

Research data were analyzed using the descriptive and comparative statistical procedures, and using the statistical software SPSS 20.0. A two-factor analysis of variance with factors Competition level (National and Regional level) and Team Position (forwards, midfielders, side defenders and central defenders) was used to evaluate the differences between the individual positions in the team. A two-factor analysis of variance with factors Competition level (National and Regional Level) and Age (16, 17 and 18 years) was used to evaluate differences between different qualitative levels.

\section{RESULTS}

Figures 1-4 show the results of the variables examined for different positions in the team, with the corresponding differences between them.

Figure 1 shows the results of the tests for assessing speed abilities sorted by position on the team, regardless of age and competition level. The results indicate statistically significant differences between forwards and midfielders in all the three observed variables: sprint at $10 \mathrm{~m}(\mathrm{p}=0.031)$, sprint at $20 \mathrm{~m}$ with flying start $(\mathrm{p}=0.0001)$ and sprint at $30 \mathrm{~m}(\mathrm{p}=0.0001)$.

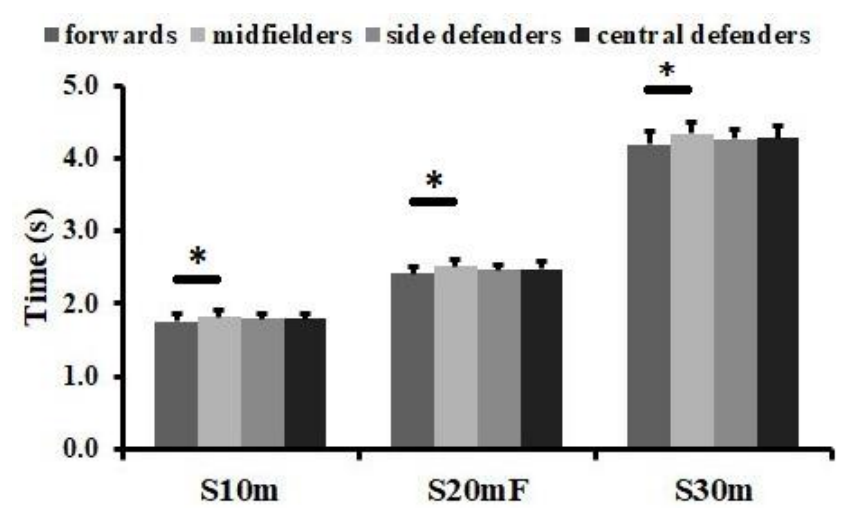

Fig. 1 Differences between playing positions in speed tests

Figure 2 shows the results of the tests for assessing agility, sorted by team position, regardless of age and competition level. As in the previous image, statistically significant differences between forwards and midfielders can be observed in the agility test without a ball ( $\mathrm{p}=0.009$ ), while there are no differences between the observed groups in the agility test with a ball. 


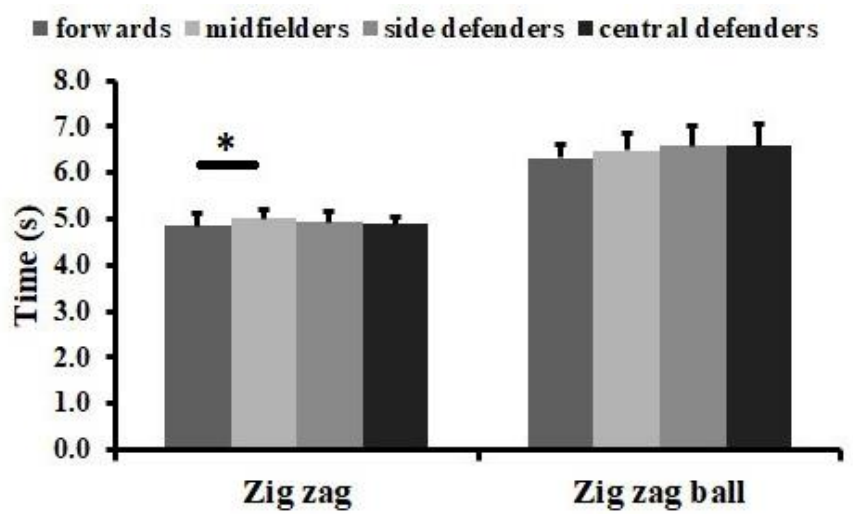

Fig. 2 Differences between playing positions in agility tests

Figure 3 shows the results of tests for the assessment of the leg muscle power based on different jump protocols sorted by team position, regardless of age and competition level. Unlike the previous cases, none of the observed variables showed a statistically significant difference between individual positions on the team.

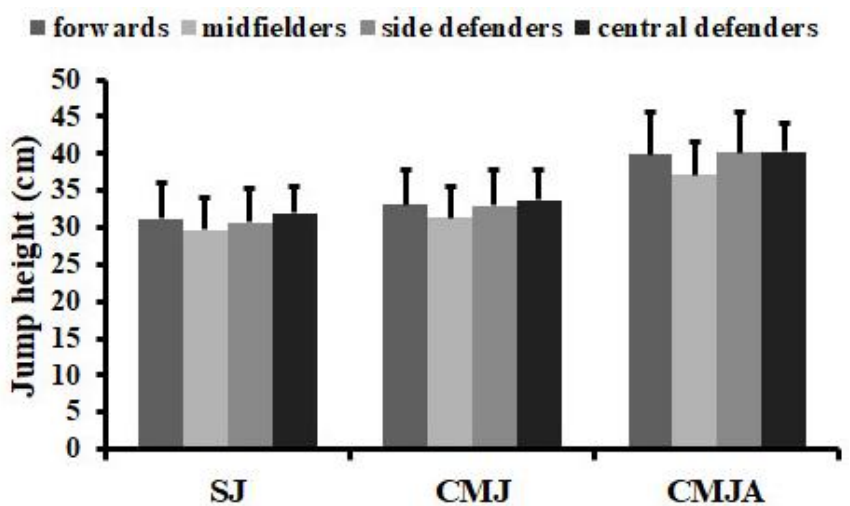

Fig. 3 Differences between playing positions in leg muscle power assessment tests

Figure 4 shows the results of the tests for the assessment of speed endurance and aerobic endurance ranked by team position, regardless of age and competition level. No test showed a statistically significant difference between the groups, except that in the speed endurance test assessed through the ratio of the best and worst attempt, the result was borderline significant in favor of midfielders against forwards $(p=0.056)$.

Regarding the test for flexibility, no significant differences were observed between the groups tested by team position (forwards: $12.6 \pm 6.7 \mathrm{~cm}$, Mean $\pm S D$; midfielders: $14.3 \pm 5.0 \mathrm{~cm}$, Mean \pm SD; side defenders: $14.4 \pm 6.1 \mathrm{~cm}$, Mean $\pm S D$; central defenders: $13.7 \pm 5.2 \mathrm{~cm}$, Mean \pm SD). 

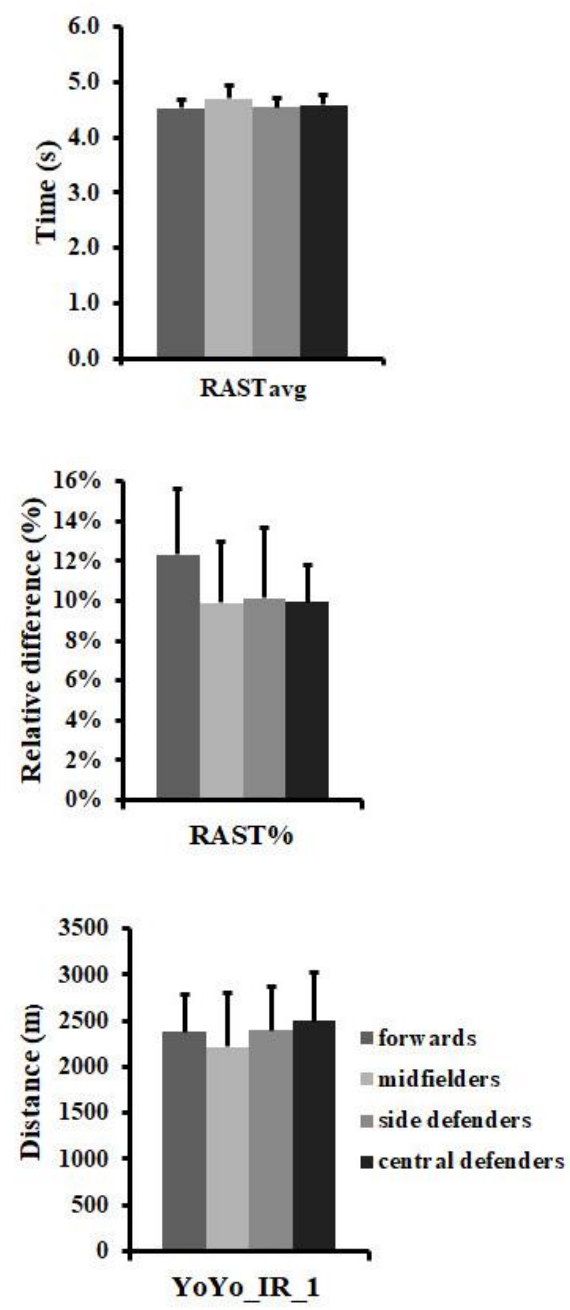

Fig. 4 Differences between playing positions in endurance assessment tests

Table 1 shows the results of a two-factor ANOVA with the factors of Competition Level and Team Position. According to the data in this table, it is observed that there is a statistically significant difference in the agility test with a ball (ZIGZAGBALL) between forwards of different levels $(\mathrm{p}=0.031)$, with better results achieved by forwards at the National level $(6.021 \pm 0.691 \mathrm{~s}$ vs. $6.528 \pm 0.388 \mathrm{~s}$, Mean \pm SD).

On the tests for assessing leg muscle power, forwards and midfielders of the Regional level scored statistically better than National level players [SJ: $32.5 \pm 4.8 \mathrm{~cm}$ vs. $29.3 \pm 4.1 \mathrm{~cm}$ for forwards, or $30.8 \pm 4.7 \mathrm{~cm}$ vs. $28.3 \pm 3.4 \mathrm{~cm}$ for midfielders; CMJ: $34.7 \pm 4.8 \mathrm{~cm}$ vs. $30.7 \pm 4.0$ $\mathrm{cm}$ for forwards and $32.9 \pm 4.2 \mathrm{~cm}$ vs. $29.4 \pm 3.4 \mathrm{~cm}$ for midfielders; CMJA: $41.7 \pm 5.2 \mathrm{~cm}$ vs. $37.3 \pm 5.3 \mathrm{~cm}$ for forwards and $38.5 \pm 7.9 \mathrm{~cm}$ vs. $35.3 \pm 3.6 \mathrm{~cm}$ (Mean \pm SD) for midfielders]. 
There are also statistically significant differences in the assessment of speed endurance over the ratio of the best and worst results. As for the results for power assessment, when assessing speed endurance, forwards and midfielders at the Regional Level achieved better results, namely, there is a relatively smaller difference between the best and worst sprints $[11.2 \pm 2.9 \%$ vs. $14.0 \pm 3.1 \%$ for forwards and $9.1 \pm 2.5 \%$ vs. $11.6 \pm 3.6 \%$ for midfielders (Mean \pm SD)]. This test was performed exclusively by U19 selections, that is, players aged 17 and 18. The reason lies in the fact that buffer systems start to develop at the age of 17, so it is considered that there was no need to test younger players. It should be noted that a modified RAST test was performed, since the original RAST test was performed for $6 * 35$ meters; in this study $6 * 30$ meters were performed, as the sprint test was performed at the same distance. Finally, National team players scored significantly better on the endurance assessment test (YoYo_Ito_1), especially midfielders [2421 $\pm 631 \mathrm{~m}$ vs. $2038 \pm 488 \mathrm{~m}$ ), and central defenders $(2926 \pm 450 \mathrm{~m}$ vs. $2250 \pm 410 \mathrm{~m}$, Mean \pm SD)].

Table 1 Two-factor ANOVA for all variables (factors: Competition level and Team position)

\begin{tabular}{|c|c|c|c|c|}
\hline $\begin{array}{l}\text { ANOVA } \\
\text { (level*position) }\end{array}$ & Forwards & Midfielders & Side defenders & Central defenders \\
\hline $\begin{array}{l}\mathrm{S} 10 \mathrm{M} \\
\mathrm{F}=0.061, p=0.980\end{array}$ & 0.573 & 0.494 & 0.972 & 0.574 \\
\hline $\begin{array}{l}\text { S20MF } \\
F=0.292, p=0.831\end{array}$ & 0.454 & 0.122 & 0.749 & 0.165 \\
\hline $\begin{array}{l}\text { S30M } \\
F=0.025, p=0.995\end{array}$ & 0.858 & 0.633 & 0.853 & 0.670 \\
\hline $\begin{array}{l}\text { ZIGZAG } \\
\mathrm{F}=0.753, \mathrm{p}=0.523\end{array}$ & 0.403 & 0.089 & 0.350 & 0.496 \\
\hline $\begin{array}{l}\text { ZIGZAGBALL } \\
\mathrm{F}=0.723, \mathrm{p}=0.540\end{array}$ & $0.031 *$ & 0.205 & 0.265 & 0.812 \\
\hline $\begin{array}{l}\text { SJ } \\
F=0.513, p=0.674\end{array}$ & $0.031 *$ & $0.048 *$ & 0.468 & 0.876 \\
\hline $\begin{array}{l}\text { CMJ } \\
F=0.719, p=0.543\end{array}$ & $0.006^{*}$ & $0.005^{*}$ & 0.338 & 0.640 \\
\hline $\begin{array}{l}\text { CMJA } \\
F=0.444, p=0.722\end{array}$ & $0.006^{*}$ & $0.020 *$ & 0.305 & 0.448 \\
\hline $\begin{array}{l}\text { RASTAVG } \\
\mathrm{F}=0.209, \mathrm{p}=0.890\end{array}$ & 0.623 & 0.715 & 0.235 & 0.655 \\
\hline $\begin{array}{l}\text { RAST\% } \\
F=0.465, p=0.708\end{array}$ & $0.020 *$ & $0.045^{*}$ & 0.522 & 0.334 \\
\hline $\begin{array}{l}\text { YOYO_IR_1 } \\
\mathrm{F}=1.315, \mathrm{p}=0.273\end{array}$ & 0.300 & $0.008 *$ & 0.448 & $0.004 *$ \\
\hline $\begin{array}{l}S \& R \\
F=0.016, p=0.997\end{array}$ & 0.415 & 0.232 & 0.390 & 0.539 \\
\hline
\end{tabular}

Figures 5-8 show the results of a two-factor analysis of variance (ANOVA) with the influence of factors Competition level and Age.

Figure 5 shows the results for assessing the ability to perform in the alactic mode, more specifically in sprinting and agility without a ball and with a ball. The difference 
between the two levels of competition is only at the age of 16 in sprinting at $20 \mathrm{~m}$ with a flying start in favor of National level players. On the other hand, in the domain of agility, a difference was observed only in agility with a ball at the age of 17 , also in favor of National level players $(\mathrm{p}=0.001)$.
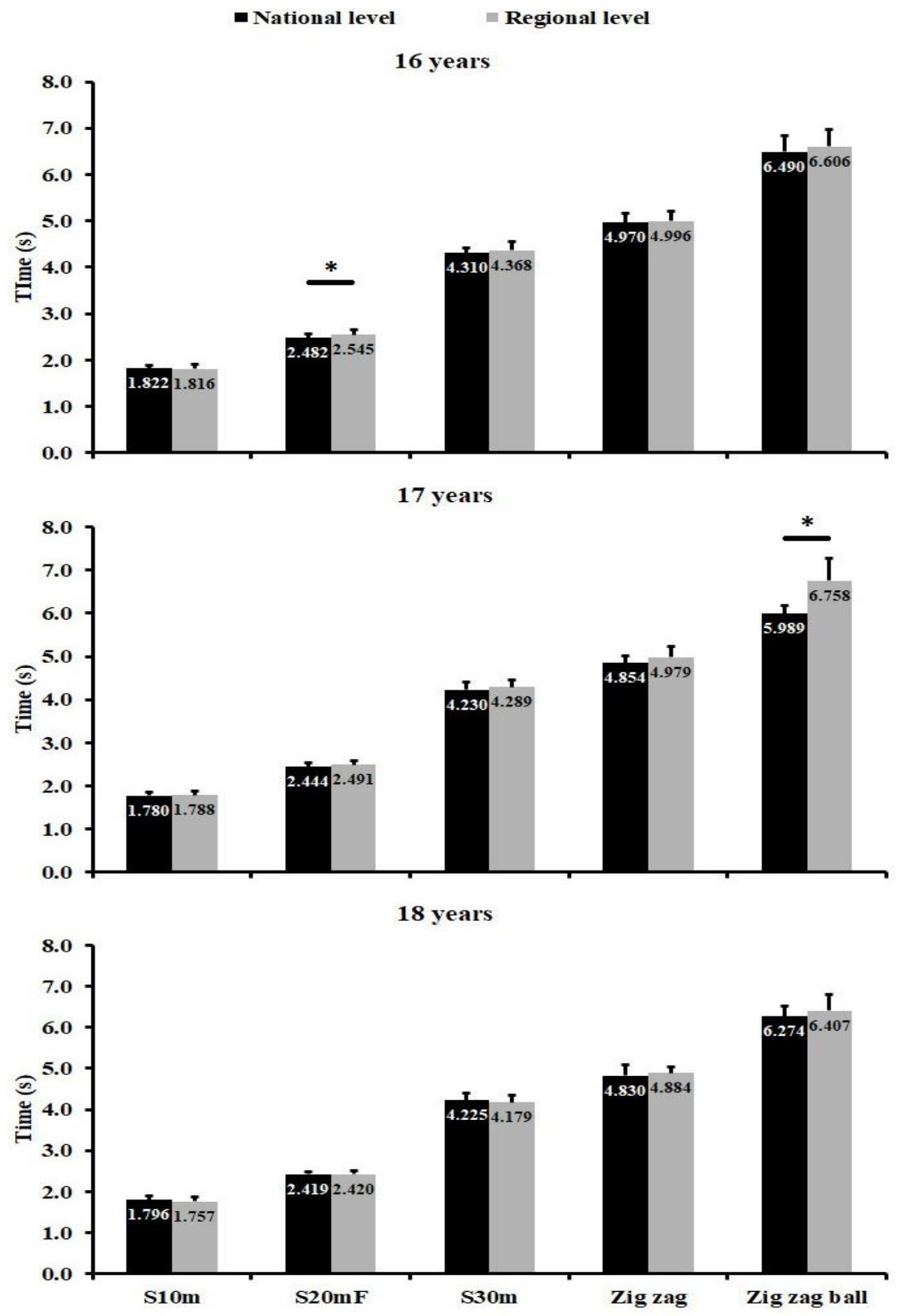

Fig. 5 Differences between competition levels in speed and agility assessment tests for each age group 
Figure 6 shows the results of the tests for the assessment of leg muscle power depending on age and competition level. Significant differences were observed with respect to the competitions level in countermovement tests at age 16, but also in all jump modalities at age 18 ( $\mathrm{p}<0.05)$, all in favor of Regional level players.
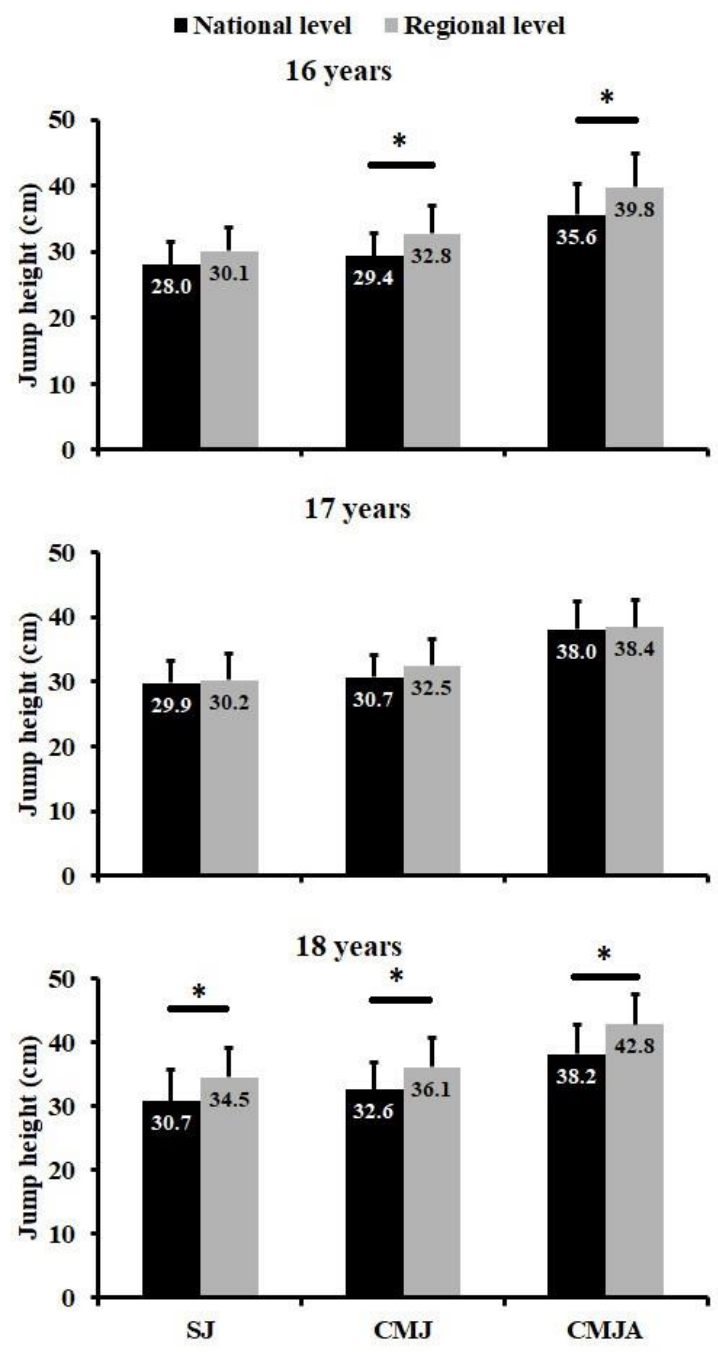

Fig. 6 Differences between competition levels in leg muscle power assessment tests for each age group 
Figure 7 shows the results of the tests for two types of endurance: speed endurance and aerobic endurance. The results indicate statistically significant differences in the assessment of speed endurance assessed by the ratio of the best and worst attempts at the age of 17 in favor of players of the Regional competition level [9.6 $\pm 2.7 \%$ vs. $12.8 \pm 2.9 \%$. cm (Mean $\pm \mathrm{SD})$; $\mathrm{p}=0.001]$. On the other hand, significant differences were observed in the endurance test at age 18 , but in favor of National level players [2817 $\pm 601 \mathrm{~m}$ vs. $2297 \pm 413 \mathrm{~m}(\mathrm{Mean} \pm \mathrm{SD})$, $\mathrm{p}=0.002]$.

\section{DNational level aRegional level \\ 16 years}

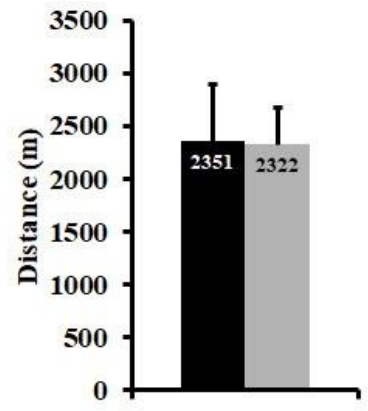

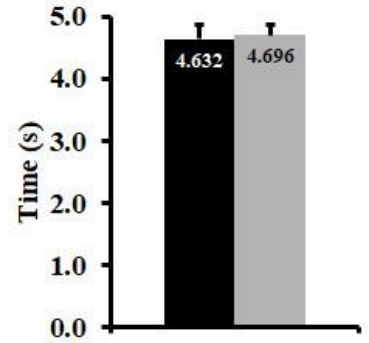

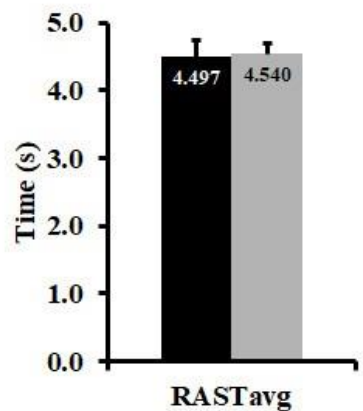

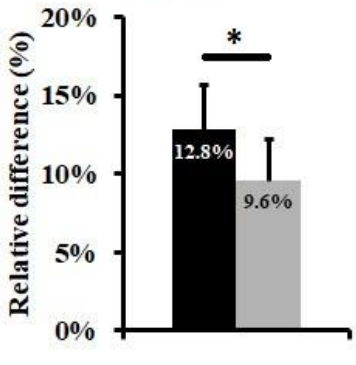

18 years

17 years

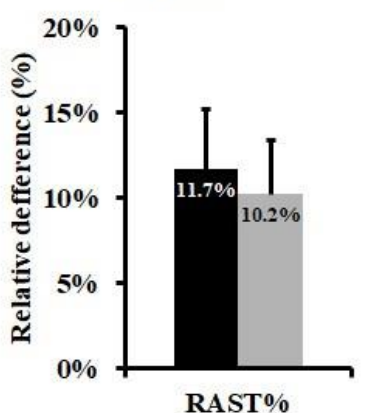

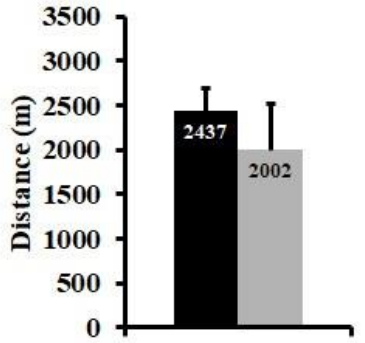

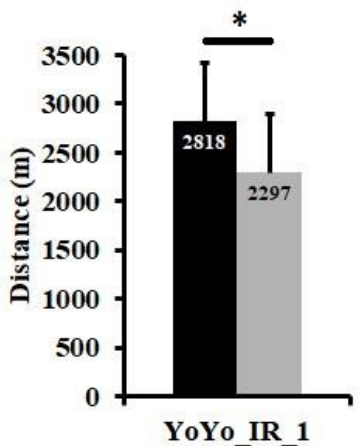

Fig. 7 Differences between competition levels in endurance assessment tests for each age group 


\section{DISCUSSION}

Prior to the discussion, it should be emphasized that the results obtained from this study could help coaches in the individualization of training programs, as well as in the further programming of the training process. Accordingly, the overall aim of this study was to determine the differences between the two levels of competition, as well as differences in team positions, based on the results obtained by a battery used to test motor skills.

In addition, some methodological aspects relevant to drawing adequate conclusions must be emphasized. First of all, it must be emphasized that positions in soccer cannot be so easily determined. Given that the common occurrence of "false nines", "half-attackers", as well as "midfield line corrector", it is difficult to determine which positions are standard. For the purpose of this paper, it was decided to define four positions, except that there was a fifth position (goalkeeper), but due to the small sample size, as well as the generally different movement structure, this position was excluded from the statistical analysis. There is also the winger position, as well as central and side midfielders that should be considered. In particular, it should be noted that this study would certainly have been more complete if another competition level was examined.

The results obtained in this study regarding the competition level show that, at least in this case, there are no significant differences in most of the variables tested, as was expected. The National level players showed the biggest difference in speed and endurance tests. Again, when looking at modern soccer, those two abilities are in fact among the most important ones for a successful game. On the other hand, the Regional level players showed the highest quality in explosive power assessment tests. Given that these were two different clubs, or two different soccer academies tested, it is possible that the results are the result of a different approach to training, that is, different selections.

Regarding the results obtained by comparing different team positions, it can be concluded that in the activities up to 5-6 seconds, or in alactic mode, the forwards are ahead of others, which is in accordance with the profile of the position they are performing, but also in line with a number of previous studies (Dauty et al., 2002; Sporiš et al., 2009; Deprez et al., 2014). Specifically, a study conducted by Gil et al. (2007) highlighted the forwards as players with the highest level of motor skills, especially when looking at youth players [age $17.31 \pm 2.64$ years $($ Mean \pm SD)] who do not play at the top level (Gil et al., 2007). Similar studies have shown that in the Norwegian league both forwards and central defenders have a higher level of alactic abilities than midfielders, indicating the importance of these abilities in young players' selection and development (Wislöff et al., 1998).

On the agility test without a ball (ZIGZAG) there is a statistically significant difference between the forwards and the midfielders. Such a result is linked to speed tests, given that agility, as an ability, is more pronounced in forwards, unlike midfielders. It is interesting to note from Figure 2 that forwards performed better than other players on the test with a ball as well. This is surprising given the fact that forwards did not use to have as good ball control at full speed with a change of direction, as midfielders for example. This information also tells us that soccer primarily focuses on the forward position. While it used to be just a classic striker, a classic "nine", with dominant motor skills, especially in jumping, as well as with a refined sense of goal and the ability to strike from any position, things are different now. Nowadays, midfielders, or midfielders behind the forwards, are closer to the goal and, in different playing systems, forwards may be wingers, or "false nines". Therefore, the occurrence of forwards with excellent technique, ball control, ball reception, ball striking is 
becoming more and more common, and there are many examples in today's soccer where we have athletic forwards with the technique of the best midfielders.

Assessment tests for explosive power of the lower extremities and the relative contribution of elastic potential (SJ, CMJ, and CMJA) showed no difference between team positions, which is in line with previous studies (Pivovarniček et al., 2013).

It is interesting to note that in this study, side defenders did not exhibit any specific ability compared to other positions on the team. On the RAST test, side defenders were expected to have the best result, but that did not happen. Given that in this position, the player should have the most pronounced ability for back and forth running, it is simply unclear how at any level and at any age they did not produce the expected results. A possible reason is that it appears that there are fewer good side defenders in present soccer, and that the players of such predispositions are getting closer to the goal, in the position of the side forwards or wingers.

Regarding the Competition level factor, the assumption was made that the players of the National level have better performance on the endurance test than their peers from the Regional level. We can find the answer in the fact that maximum oxygen consumption (VO2max) is one of the basic predictors of top soccer, and therefore, if two levels are involved, it is logical that a higher level has greater demands in play and movement. As for speed endurance, the results depend solely on the coach's training methods, with the RAST test as a measure of player fitness. The results are expected to improve with age and competition level (Abrantes, Maçãs, \& Sampaio, 2004), and reasons for unexpected results (regional level players better than national level players) should be sought in the fact that buffering systems responsible for this ability start to develop at the age of 17 , so this ability still does not differentiate players of this age.

\section{CONCLUSIONS}

This research aimed to prove the assumptions that motor skills differentiate players based on their competition level and position on the team. In addition, it aimed to prove that forwards and central defenders are the best in alactic activities, as well as that midfielders are the best in aerobic activities, and that side defenders are the best in lactic activities. The results of this research indicate that motor skills do not differentiate players by competition level, which is explained with the way their training sessions are prepared. Since the testing was conducted after the teams had passed the preparatory period, there is a possibility that the coaches may have had different goals during the preparation. Since the gap exists in the U19 selection in aerobic endurance that underlies soccer performance, it can nevertheless be argued that this hypothesis is partially confirmed.

In terms of team positions, it can definitely be argued that motor skills differentiate players in particular positions. However, individually, the alactic abilities of the speed and agility type have been shown to differentiate forwards from other positions, especially from midfielders. Therefore, it can be argued that the hypothesis that forwards and central defenders are better than other positions in alactic activity is only partially confirmed.

Apart from these results, there is a slight ambiguity about the position of the side defenders, since the expected results have not been achieved. This means that in some future studies, particular attention must be paid to this position, given that side defenders can play both defense and attack. 


\section{REFERENCES}

Abrantes, C., Maçãs, V., \& Sampaio, J. (2004). Variation in football player's sprint test performance across different ages and levels of competition. Journal of Sports Science and Medicine, 3(YISI 1), 44-49.

Andrzejewski, M., Chmura, J., Pluta, B., Strzelczyk, R, \& Kasprzak, A. (2013). Analysis of sprinting activities of professional soccer players. Journal of Strength and Conditioning Research, 27(8), 2134-2140

Arnason, A., Siqurdsson, S.B., Gudmundsson, A., Holme, I., Engebretsen, L., \& Bahr, R. (2004). Physical fitness, injuries, and team performance in soccer. Medicine and Science in Sports and Exercise, 36(2), 278-285.

Boone, J., Vaeyens, R., Steyaert, A., Vanden Bossche, L., \& Bourgois, J. (2012). Physical fitness of elite Belgian soccer players by player position. Journal of Strength and Conditioning Research, 26(8), 2051-2057.

Casajüs, J.A. (2001). Seasonal variation in fitness variables in professional soccer players. Journal of Sports Medicine and Physical Fitness, 41(4), 463-469.

Cometti, G., Maffiuletti, N.A., Pousson, M., Chatard, J.C., \& Maffulli, N. (2001). Isokinetic strength and anaerobic power of elite, subelite and amateur French soccer players. International journal of sports medicine, 22(1), 45-51.

Dauty, M., Bryand, F., \& Potiron-Josse, M. (2002). Relation entre la force isocinétique, le sautet le sprint chez le footballeur de haut niveau (Relation between isokinetic force, leap and sprint in high level footballer). Science and Sports, 17(3), 122-127. In French

Deprez, D., Fransen, J., Boone, J., Lenoir, M., Philippaerts, R., \& Vaeyens, R. (2015). Characteristics of high-level youth soccer players: Variation by playing position. Journal of Sports Sciences, 33(3), 243-254.

Di Salvo, V., Baron, R., Tschan, H., Calderon, M., Bachl, N., \& Pigozzi, F. (2007): Performance characteristics according to playing position in elite soccer. International Journal of Sports Medicine, 28(3), 222-227.

Gil, S., Ruiz, F., Irazusta, A., Gil, J., \& Irazusta, J. (2007). Selection of young soccer players in terms of anthropometric and physiological factors. Journal of Sports Medicine and Physical Fitness, 47(1), 25-32.

Haugen, T.A., Tønnessen, E., \& Seiler, S. (2013). Anaerobic performance testing of professional soccer players 1995-2010. International Journal of Sports Physiology and Performance, 8(2), 148-156.

Joksimović, A., Joksimović I., \& Joksimović, S. (2008). Antropološke karakteristike fudbalera u odnosu na rang takmičenja (Anthropological characteristics of football players in relation to competition rank). Glasnik Antropološkog društva Srbije, 43, 271-282. In Serbian

Jovanović, M., Sporiš, G., Omrcen, D., \& Fiorentini, F. (2011). Effects of speed, agility, quickness training method on power performance in elite soccer players. Journal of Strength and Conditioning Research, 25(5), 1285-1292.

Kalapotharakos, V.I., Strimpakos, N., Vithoulka, I., Karvounidis, C., Diamantopoulos, K., \& Kapreli, E. (2006). Physiological characteristics of elite professional soccer teams of different ranking. The Journal of Sports Medicine and Physical Fitness, 46(5), 515-519.

Krustrup, P., Mohr, M., Nybo, L., Jensen, J.M., Nielsen, J.J., \& Bangsbo, J. (2006). The Yo-Yo IR2 test: physiological response, reliability, and application to elite soccer. Medicine and Science in Sport and Exercise, 38(9), 1666-1673.

Lago-Penas, C., Lago-Ballesteros, J., \& Rey, E. (2011). Differences in performance indicators between winning and losing teams in the UEFA champions league. Journal of Human Kinetics, 27(1), 135-146.

Mohr, M., Krustrup, P., \& Bangsbo, J. (2003). Match performance of high-standard soccer players with special reference to development of fatigue. Journal of Sport Sciences, 21(7), 519-28.

Pivovarniček, P., Pupiš, M., Tonhauserová, Z., \& Tokárová, M. (2013). Nivo sprinterskih sposobnosti, eksplozivne snage i specijalne izdržljivost vrhunskih mladih fudbalera na različitim pozicijama (Level of sprinting skills, explosive power and special endurance of top young footballers at various positions). SportLogia, 9(2), 109117. In Serbian

Psotta, R., Bunc, V., Netscher, J., Mahrová, A., \& Nováková, H. (2006). Fotbal-kondičnítrénink (Football fitness training). Praha, CZ: Grada. In Czech

Rampinini, E., Bishop, D., Marcora, S.M., Ferrari Bravo, D., Sassi, R., \& Impellizzeri, F.M. (2007). Validity of simple field tests as indicators of match-related physical performance in top-level professional soccer players. International Journal of Sports Medicine, 28(3), 228-235

Rebelo, A., Brito, J., Maia, J., Coelho-e-Silva, M.J., Fiquueiredo, A.J., Bangsbo, J., et al. (2013). Anthropometric characteristics, physical fitness and technical performance of under-19 soccer players by competitive level and field position. International Journal of Sports Medicine, 34(4), 312-7

Reilly, T., Bangsbo, J., \& Franks, A. (2000). Anthropometric and physiological predispositions for elite soccer. Journal of Sports Sciences, 18(9), 669-683.

Reilly T, Williams, A.M., Nevill, A., \& Franks, A. (2000). A multidisciplinary approach to talent identification in soccer, Journal of sports sciences, 18(9), 695-702. 
Rostgaard, T., Iaia, F.M., Simonsen, D.S., \& Bangsbo, J. (2008). A test to evaluate the physical impact on technical performance in soccer. Journal of Strength and Conditioning Research, 22(1), 283-292.

Sever, O., \& Zorba, E. (2018). Investigation of physical fitness levels of soccer players according to position and age variables. Facta Universitatis Series Physical Education and Sport, 295-307.

Sporiš, G., Jukić, I., Ostojić, S.M., \& Milanović, D. (2009). Fitness profiling in soccer: physical and physiological characteristics of elite players. Journal of Strength and Conditioning Research, 23(7), 1947-1953.

Stølen, T., Chamari, K., Castagna, C., \& Wisløff, U. (2005). Physiology of soccer: an update. Sports Medicine, 35(6), 501-536.

Strudwick, A., Reilly, T., \& Doran, D. (2002). Anthropometric and fitness profiles of elite players in two football codes. Journal of Sports Medicine and Physical Fitness, 42(2), 239-242.

Taskin, H. (2008) Evaluating sprinting ability, density of acceleration, and speed dribbling ability of professional soccer players with respect to their positions. The Journal of Strength and Conditioning Research, 22(5), 14811486.

Verheijen, R. (1998). The complete handbook of conditioning for soccer. Reedswain, Spring City, PA

Vaeyens, R., Malina, R., Janssens, M., Renterghem, B., Bourgois, J., Vrijens, J., et al. (2006). A multidisciplinary selection model for youth soccer: the Ghent Youth Soccer Project. British Journal of Sports Medicine, 40(11), 928-134.

Wislöff, U., Helgerud, J., \& Hoff, J. (1998). Strength and endurance of elite soccer players. Medicine and Science in Sports and Exercise, 30(3), 462-467.

Wisløff, U., Castanga, C., Helgerud, J., Jones, R., \& Hoff, J. (2004). Strong correlation of maximal squat strength with sprint performance and vertical jump height in elite soccer players. British Journal of Sports Medicine, 38(3), 285-298.

Wong, D.P., \& Wong, S.H.S. (2009). Physiological profile of Asian elite youth soccer players. Journal of Strength and Conditioning Research, 23(5), 1383-1390.

\section{FUNKCIONALNE SPOSOBNOSTI FUDBALERA PREDPUBERTETSKOG UZRASTA U FUNKCIJI RANGA TAKMIČENJA I POZICIJE U TIMU}

Cilj rada je da se ispitaju razlike u motoričkim sposobnostima fudbalera uzrasta 16 - 18 godina koji igraju u različitim nivoima takmičenja (Lige Srbije i Lige Beograda), kao i fudbalera koji igraju na različitim pozicijama u fudbalskom timu. Za procenu motoričkih sposobnosti korišćena je standardna baterija testova za procenu motoričkih sposobnosti fudbalera. Za procenu razlika između pojedinih pozicija u timu korišćena je dvofaktorska analiza varijanse sa faktorima rang takmičenja (Savezni i Regionalni rang) i pozicije u timu (napadač, vezni, spoljni $i$ odbrambeni). Za procenu razlika između različitih kvalitativnih nivoa primenjena je dvofaktorska analiza varijanse sa faktorima rang takmičenja (Savezni i Regionalni rang) i uzrast (16, 17 i 18 godina). Istraživanjem je obuhvaćeno 126 momaka, uzrasta od 16 do 18 godina $\left(N_{16}=45, N_{17}=41, N_{18}=40\right)$, podeljenih na 4 pozicije: napadač $(N=37, V T=179.2 \pm 5.0, M T=70.1 \pm 6.6)$, vezni $(N=48, V T=177.9 \pm 6.3, M T=69.6 \pm 7.9)$, spoljni $(N=22, V T=176.6 \pm 5.4, M T=67.5 \pm 5.7)$ i odbrambeni igrači $(N=19, V T=184.0 \pm 4.3, M T=72.3 \pm 6.6)$. Kako se aktivnosti golmana u osnovi značajno razlikuju od ostalih igrača, pozicija golmana je isključena. Rezultati istraživanja navode da motoričke sposobnosti ne diferenciraju igrače prema rangu takmičenja, kao i da postoji razika u uzrastu 18 godina u aerobnoj izdržljivosti koja je osnova uspešnosti u fudbalu. Dobijeni rezultati ukazuju da se može tvrditi da motoričke sposobnosti diferenciraju igrače na pojedinim pozicijama. Međutim, pojedinačno gledano jedino se pokazalo da alaktatne sposobnosti tipa brzine i agilnosti, diferenciraju napadače od ostalih pozicija, naročito od veznih igrača u fudbalskoj igri.

Ključne reči: fudbal, motoričke sposobnosti, pozicije u fudbalskom timu, nivo takmičenja, mladi fudbaleri 